\title{
The Role of Groundwater in Eutrophication of a Lake in Glacial Outwash Terrain
}

\author{
by \\ David Robert LEE*
}

\section{INTRODUCTION}

Several writers (e.g. Hasler and Ingersoll, 1968; Rose, 1972) have suggested that nutrients, leached into groundwater from land waste disposal or agricultural fertilizers, pose an enrichment hazard to surface waters. Schraufnagel and others (1967), for example, estimated that $42 \%$ of the nitrogen and $2.3 \%$ of the phosphorus reaching surface waters in Wisconsin came from groundwater.

But the investigator of groundwater inflow confronts the following problems:

1. Methodology for site specific study of nutrient input via groundwater is severely lacking (Uttormark et al., 1974).

2. Evidence that groundwater inflow is responsible for lake enrichment appears entirely inferential.

3. There are no detailed studies of the long term changes which follow lakeshore development.

4. Records rarely exist of groundwater nutrient concentrations prior to various land use practices.

Popov (1972) has emphasized the importance of finding methods to study the interaction of surface and groundwater in order to estimate changes due to various economic activities.

Lakes in glacial-drift terrain are normally related to the near surface groundwater system (Stephenson, 1971). In moderately permeable, unconsolidated material, the flow of groundwater into or out of a lake may be diffused over wide areas of lake bed. In some areas inflow may be measured directly.

This study sought to estimate the groundwater transport of nutrients to Lake Sallie, west-central Minnesota, U.S.A. $\left(46^{\circ} 46^{\prime}\right.$ N., $95^{\circ} 54^{\prime}$ W.). This lake was 
selected for study because it receives a large net groundwater inflow; in 1970, for example, the net groundwater inflow was $16 \%$ of the total inflow (Mann and McBride, 1972). During 1970, surface flow contributed $7.2 \times 10^{3} \mathrm{~kg}$ of phosphorus and removed $2.6 \times 10^{3} \mathrm{~kg}$ of that same element; that same year, surface flow added $1.6 \times 10^{4} \mathrm{~kg}$ of nitrogen and removed $1.8 \times 10^{4} \mathrm{~kg}$ of nitrogen (Peterson et al., 1974). Lake Sallie has a surface area of 489 ha and a mean depth of $5.6 \mathrm{~m}$. In recent years, this lake has produced dense blooms of blue.green algae. The growth of aquatic plants was of such magnitude that this site was selected as an experimental area for large-scale harvest of aquatic plants.

\title{
METHODS
}

\begin{abstract}
Measurement and Collection of Groundwater Inflow
Groundwater flow into the lake was collected by covering a $0.258 \mathrm{~m}^{2}$ area of lake bed with a bottomless cylinder (seepage meter) vented to a deflated plastic bag (Lee, 1975). The cylinder was pushed slowly, open end down, into the lake bed until its closed end was about $4 \mathrm{~cm}$ above the sediment. It was positioned to elevate the vent hole slightly so that gas, originating in the sediment, could freely escape. The cylinder was left for two days to enable benthic organisms to escape, and then a stopper with tube was inserted into the cylinder hole. To collect a sample, a deflated plastic bag was connected to the tube, and left for 1 to 6 hours until it contained a $1 / 2$ to 3 liter sample. The sample volume was measured and a portion retained for chemical analysis. To permit groundwater flow, seepage meters were left in position with tubes open to the lake between sampling times. Where seepage velocity was low, measurement required several days and in some areas there was no apparent flow.
\end{abstract}

Seepage velocity was calculated using the equation

$\frac{\text { liters of water in the bag }}{\text { hours of elapsed time }} \times 1.075=$ velocity as $\mu \mathrm{m} / \mathrm{s}$.

The factor 1.075 converts liters per hour and area of cylinder to seepage velocity as micrometers per second. Expressed as $\mu \mathrm{m} / \mathrm{s}$, seepage velocity is numerically equivalent to discharge as milliters per second from a square meter of lake bed. Seepage velocity should not be confused with interstitial velocity which is equal to 100 multiplied by the seepage velocity divided by the percent porosity of sediment.

\section{Chemical Analysis}

Water samples were either frozen and analyzed several weeks later or stored at 0 to $5 \mathrm{C}$ and analyzed within 48 hours after collection. Analyses for ammonia, nitrite and nitrate nitrogen, and for soluble orthophosphate were performed according to Standard Methods (American Public Health Association, 1965, 1971). Samples were analyzed for total phosphate using the persulfate procedure of the U. S. Environmental Protection Agency (Dominick, 1971). Filtration through medium grade filter paper (Sargent 501 or equivalent) preceded all analyses except ammonia and total phosphate.

\section{RESULTS AND DISCUSSION}

\section{Seepage Meters as Groundwater Collection Devices}

Can seepage meters be used to obtain site-specific samples of groundwater for phosphorus and nitrogen analyses? When the seepage meter is pushed into the 
lake bed, sediment particles and interstitial spaces are disturbed and the lake bed is isolated from the overlying water. Nutrients could be released from the surficial sediments not only from particle rearrangement, but also from readjustments in the benthic community. Beneath the seepage meter, the lake bed receives neither light nor food resources from the lake water. Under natural conditions, lake currents may penetrate the sediment. However, the presence of a seepage meter prevents any lake-induced circulation and consequent chemical equilibria.

The potential of using seepage meters for collection of groundwater was tested in the following way: 1) an area of uniform groundwater discharge was located; 2) a flow net was drawn to show the theoretical flow path of groundwater into the lake; 3 ) wells were placed to intercept water before it reached the lake, and adjacent to these wells, seepage meters were placed to collect water as it entered the lake; and 4) water was collected from the wells and seepage meters for several months and analyzed for phosphorus and nitrogen. If phosphorus and nitrogen concentration of water from the wells was similar to that of the seepage meters, then it could be concluded that seepage meters can be used to obtain site-specific measurements of groundwater nutrient transport.

1. Relatively uniform, steady, seepage velocity was found along the southwestern shoreline of Lake Sallie. Seepage was greatest $(0.3$ to $0.8 \mu \mathrm{m} / \mathrm{s})$ near the shore and it decreased with distance from the shore.

2. A flow net (constructed according to rules provided by Cedergren, 1968) showed that shallow groundwater was discharged near the shore while deeper groundwater was discharged farther from shore.

3. Twelve wells, driven 1 to $2.2 \mathrm{~m}$ into the water table, were sampled 8 times over a period of 108 days. Four seepage meters, placed near the shoreline, were sampled at least 8 times over a period of at least 112 days.

4. Orthophosphate concentration of water from the seepage meters was similar to water from the wells. (Table 1 gives the data collected from the four seepage meters - 14B, 14E, 14K, 14N - after more than 1,200 liters of groundwater had flowed through them.) The nutrient content of 4 wells was clearly affected by a nearby septic tank. In the unaffected wells, average orthophosphate levels ranged from 0.15 to $0.30 \mathrm{mg} / \mathrm{l}$. Seepage velocity ranged from 0.4 to $0.8 \mu \mathrm{m} / \mathrm{s}$. Water collected from the seepage meters initially contained highly variable concentrations of orthophosphate $(0.21$ to $1.15 \mathrm{mg} / \mathrm{l}, \mathrm{Fig}$. 1), with the average concentration being $0.15 \mathrm{mg} / 1$ after 1,200 liter of flow-through.

Ammonia nitrogen levels in the seepage inflow were initially high but there was a steady decline over a 2 month period of time. After 9001 of flow-through, ammonia levels in all seepage meters (except 14E) dropped below $0.25 \mathrm{mg} / \mathrm{l}$, and after 2,380 $\mathrm{l}$ the ammonia level for $14 \mathrm{~B}$ fell below $0.01 \mathrm{mg} / \mathrm{l}$. One seepage meter, 14E, seemed to be strongly affected by the septic tank; it consistently contained over $2 \mathrm{mg} / \mathrm{l}$ ammonia nitrogen even after 4,050 liters of groundwater had passed through it (Table 1). It is significant to note that the phosphate concentration in this seepage meter was not greater than that in the other seepage meters at this site.

Average nitrate concentrations in the shallow wells ranged from 12.4 to 59.1 
$\mathrm{mg} / 1 \mathrm{~N}$. Monthly samples from a well $57 \mathrm{~m}$ from the edge of the lake contained 1.57 to $0.34 \mathrm{mg}$ nitrate nitrogen/l initially, but after the well was driven $0.5 \mathrm{~m}$ deeper, nitrate levels fell to less than 0.012 . This indicated that a high-nitrate zone capped the water table. The seepage inflow $7 \mathrm{~m}$ from shore (14B and 14E) contained nitrate concentrations that ranged from 8.8 to $16.0 \mathrm{mg} \mathrm{N} / 1$, but in ground water discharged $12 \mathrm{~m}$ and $17 \mathrm{~m}$ from shore (14K and $14 \mathrm{~N}$, respectively), nitrate concentrations were less than $0.005 \mathrm{mg} / 1 \mathrm{~N}$. This information concurred with the theoretical flow net: deeper groundwater, discharged farther from shore, was low in nitrate, whereas shallow groundwater, discharged near the shoreline was high in nitrate.

In conclusion, the theoretical flow net and comparison of phosphorus and nitrogen in well and seepage water indicated that seepage meters could be used in high velocity discharge areas (greater than $0.4 \mu \mathrm{m} / \mathrm{s}$ ) to obtain site specific water samples of groundwater for nutrient analyses.

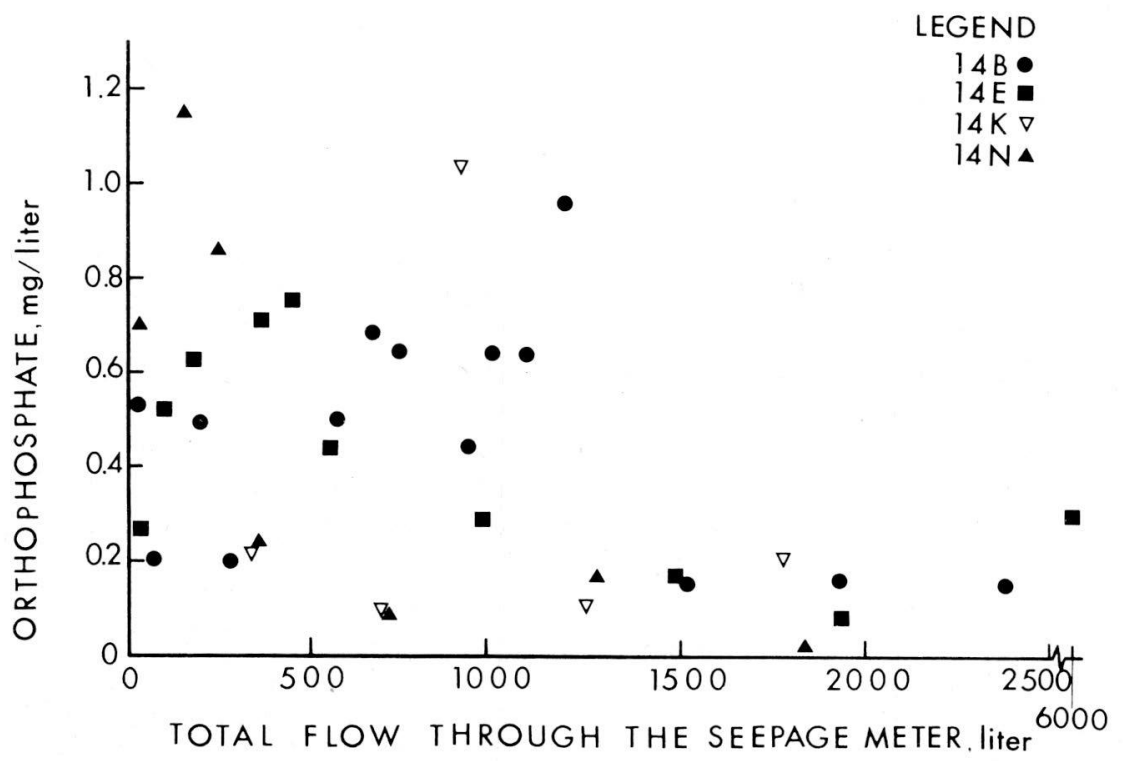

Fig. 1. Phosphate concentration versus total flow through a seepage meter.

\section{Nutrient Influx from Groundwater}

Seepage measurements were attempted at intervals of less than $0.5 \mathrm{~km}$ along the entire margin of the lake and three major inflow areas were identified. 
An area of evenly distributed inflow was located along the southwestern shoreline of the lake from $0.5 \mathrm{~km}$ north to $1.0 \mathrm{~km}$ south of $14 \mathrm{~B}$. Extensive seepage measurements were made in this area (fig. 2). There were no significant changes in seepage velocity from July through December, 1971 (Table 1, Figure 2). Based on flow rates for this 6 month period, the annual groundwater inflow over the $800 \mathrm{~m}$ shoreline (Figure 2, the area between I and VI) was $4.5 \times$ $10^{5} \mathrm{~m}^{3}$. Based on an average total phosphate value of $0.25 \mathrm{mg} \mathrm{PO}_{4} / 1$, the groundwater inflow along this shoreline transported $37 \mathrm{~kg}$ of phosphorus per year into the lake.

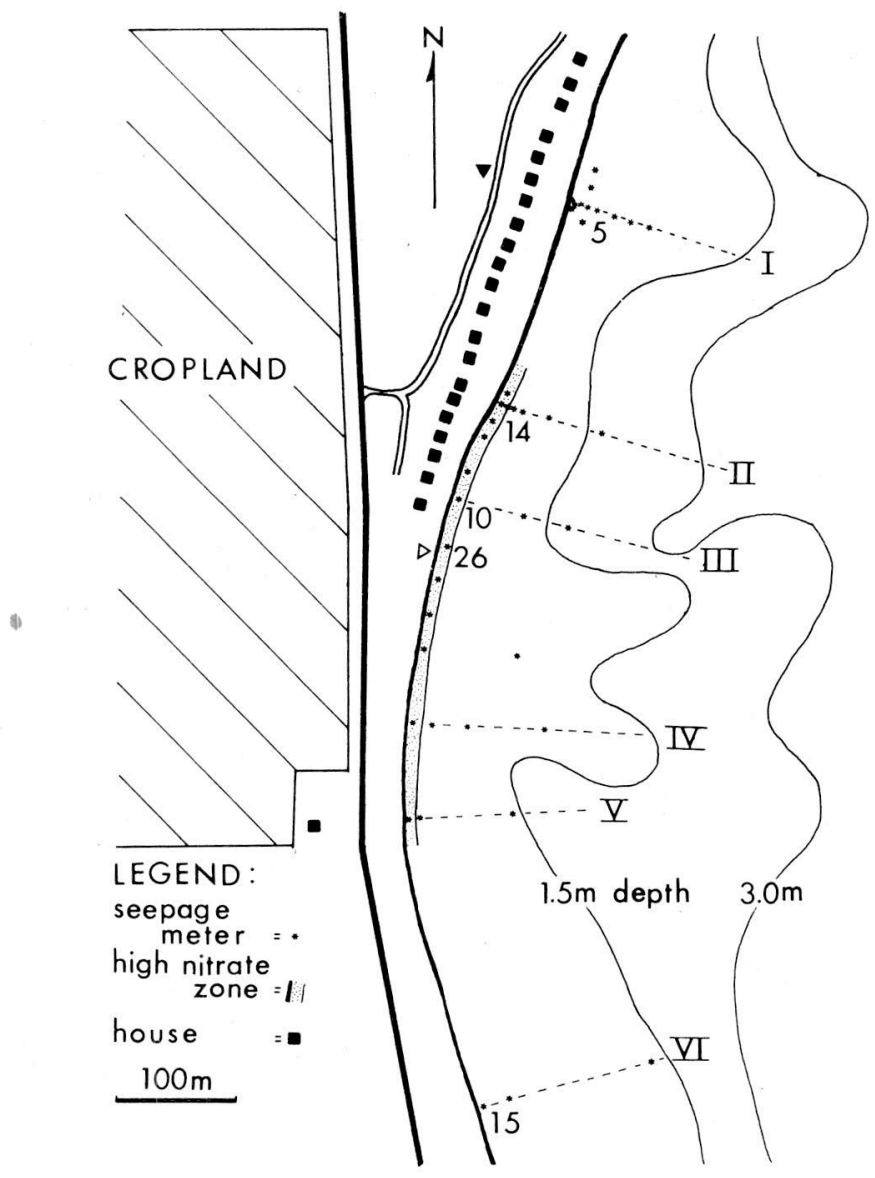

Fig. 2. Southwestern shoreline of Lake Sallie showing seepage measurement points $\left({ }^{*}\right)$ and position of transects (IV). 


\begin{tabular}{|c|c|c|c|c|c|c|c|}
\hline \multirow[b]{2}{*}{$\begin{array}{l}\text { Seepage } \\
\text { meter }\end{array}$} & \multirow[b]{2}{*}{ Date } & \multirow{2}{*}{$\begin{array}{c}\text { Liters } \\
\text { through } \\
\text { meter* }\end{array}$} & \multirow[b]{2}{*}{$\begin{array}{c}\text { Velocity } \\
\mu \mathrm{m} / \mathrm{s}\end{array}$} & \multicolumn{2}{|c|}{$\mathrm{mg} \mathrm{PO}_{4} / \mathrm{l}$} & \multicolumn{2}{|c|}{$\mathrm{mg} \mathrm{N} / \mathrm{l}$} \\
\hline & & & & $\begin{array}{c}\text { Ortho- } \\
\text { phosphate }\end{array}$ & $\begin{array}{c}\text { Total } \\
\text { phosphate }\end{array}$ & $\begin{array}{c}\text { Ammonia } \\
\text { nitrogen }\end{array}$ & $\begin{array}{c}\text { Nitrate } \\
\text { nitrogen }\end{array}$ \\
\hline $5 \mathrm{~K}$ & $30 \mathrm{Dec}$ & 3,280 & 0.805 & 0.14 & 0.40 & 0.36 & 0.005 \\
\hline 10 & $11 \mathrm{Dec}$ & 1,510 & 0.542 & 0.19 & 0.28 & 0.05 & 8.00 \\
\hline 10 & $30 \mathrm{Dec}$ & 1,670 & 0.348 & 0.19 & 0.12 & 0.00 & 9.5 \\
\hline 10 & 26 May & $3,070 * *$ & 1.14 & 0.10 & 0.16 & 0.28 & 2.92 \\
\hline $14 \mathrm{~B}$ & $26 \mathrm{Oct}$ & 1,510 & 0.623 & 0.15 & 0.54 & 0.13 & 10.0 \\
\hline $14 \mathrm{~B}$ & 27 Nov & 1,930 & 0.276 & 0.16 & 0.20 & 0.08 & 12.3 \\
\hline $14 \mathrm{~B}$ & $30 \mathrm{Dec}$ & 2,380 & 0.543 & 0.14 & 0.32 & 0.00 & 8.8 \\
\hline $14 \mathrm{E}$ & 27 Nov & 1,460 & 0.764 & 0.17 & 0.22 & 2.09 & 13.2 \\
\hline $14 \mathrm{E}$ & $30 \mathrm{Dec}$ & 1,940 & 0.487 & 0.08 & 0.32 & 3.4 & 14 \\
\hline $14 \mathrm{E}$ & 26 May & $4,050 * *$ & 1.03 & 0.30 & 0.30 & 2.48 & 16.0 \\
\hline $14 K$ & 27 Nov & 1,240 & 0.492 & 0.11 & 0.20 & 0.17 & 0.003 \\
\hline $14 \mathrm{~K}$ & $30 \mathrm{Dec}$ & 1,780 & 0.743 & 0.21 & 0.32 & 0.20 & 0.003 \\
\hline $14 \mathrm{~N}$ & 27 Nov & 1,270 & 0.747 & 0.17 & 0.28 & 0.11 & 0.002 \\
\hline $14 N$ & $30 \mathrm{Dec}$ & 1,830 & 0.650 & 0.02 & 0.28 & 0.16 & 0.004 \\
\hline 15 & $11 \mathrm{Dec}$ & 1,510 & - & 0.16 & 0.24 & 0.28 & 0.002 \\
\hline
\end{tabular}




\begin{tabular}{llllllll}
26 & $30 \mathrm{Dec}$ & 1,430 & 0.484 & 0.12 & 0.32 & 0.28 & 3.40 \\
$31 \mathrm{E}$ & $24 \mathrm{Sep}$ & 1,420 & 1.05 & 0.17 & 0.40 & 0.74 & 0.002 \\
$31 \mathrm{E}$ & $16 \mathrm{Oct}$ & 1,940 & 1.06 & 0.36 & 0.40 & 0.83 & 0.003 \\
$31 \mathrm{E}$ & $29 \mathrm{Oct}$ & 2,250 & 1.32 & 0.16 & 0.78 & 1.02 & 0.002 \\
& & & & & & \\
$32 \mathrm{C}$ & $24 \mathrm{Sep}$ & 1,360 & 2.42 & 1.30 & 1.92 & 3.71 & 0.001 \\
$32 \mathrm{C}$ & $16 \mathrm{Oct}$ & 2,470 & 1.99 & 1.02 & 1.80 & 4.0 & 0.002 \\
$32 \mathrm{C}$ & $29 \mathrm{Oct}$ & 3,120 & 1.82 & 1.14 & 1.88 & 3.85 & 0.002 \\
\hline
\end{tabular}

* This column shows the volume of water which flowed through the meter before the sample was collected. The average flow during the preceeding months was used to calculate this number.

**This number was calculated using the average flow during the autumn months. 
A large nitrate input (2.19 to $50.4 \mathrm{mg} \mathrm{N} / 1$ at $0.5 \mu \mathrm{m} / \mathrm{s}$ ) occurred within $8 \mathrm{~m}$ of the shoreline between II and V (Fig. 1). Outside this area, seepage inflow contained less than $0.022 \mathrm{mg} / \mathrm{l}$ nitrate nitrogen. The highest nitrate concentrations were found in seepage collected along the shore where septic tanks were used; the conclusion that septic tanks contribute nitrogen to the lake was inescapable. Substantial quantities of nitrate were found in the nearshore seepage all the way to the southern end of the cultivated land. Most of this land received $1.9 \mathrm{~g}$ nitrogen $/ \mathrm{m}^{2}$ per year in fertilizer. Per unit length, the nitrate discharged along this shoreline was equal to the nitrogen application on the adjacent cropland; this suggested additional sources. Using an average value of $4.83 \mathrm{mg} \mathrm{N} / 1$, the nitrate influx via groundwater in the high nitrate zone was $261 \mathrm{~kg} \mathrm{~N} / \mathrm{yr}$. In the remainder of the area, nitrate averaged only $0.005 \mathrm{mg} \mathrm{N} / 1$. Using an average value of $0.20 \mathrm{mg} \mathrm{N} / \mathrm{l}$, the ammonia influx for the entire 0.13 $\mathrm{km}^{2}$ area was $90 \mathrm{~kg} \mathrm{~N} / \mathrm{yr}$. Nitrite seldom amounted to more than $0.01 \mathrm{mg} \mathrm{N} / 1$. Thus, the total inorganic nitrogen influx from groundwater in this area was $351 \mathrm{~kg} \mathrm{~N} / \mathrm{yr}$.

Two other major inflow areas were located along the northeastern shoreline of Lake Sallie. One area, about $0.5 \mathrm{~km}$ in length, was associated with a land mass $0.2 \mathrm{~km}$ wide separating Muskrat Lake and Lake Sallie. Inflow in this area was unevenly distributed along the shoreline and, in some places, there was no measureable flow. A seepage meter was placed in the highest velocity location found in this area (Table 1, 32C). Another major inflow area extended alongshore from $0.7 \mathrm{~km}$ to at least $0.9 \mathrm{~km}$ south of the Pelican River inlet. In this area, seepage was relatively uniform $(0.3$ to $1.1 \mu \mathrm{m} / \mathrm{s})$. Seepage meter $31 \mathrm{E}$ was used to monitor this flow (Table 1).

Comparison of inflow quality at the two inflow areas monitored by $31 \mathrm{E}$ and $32 \mathrm{C}$ suggested that groundwater may carry nutrients from one lake to another. Nutrient rich inflow at $32 \mathrm{C}$ (approximately $0.5 \mathrm{mg}$ total phosphate/l) may have represented seepage flow from highly eutrophic Muskrat Lake into Lake Sallie. Inflow at $31 \mathrm{E}$ may have been derived from local groundwater recharge or, as McBride's data suggest (McBride, 1972), it may have come from Lake Detroit $1.6 \mathrm{~km}$ away.

The total influx of nutrients via groundwater was insignificant compared to the large quantities of nutrients carried into Lake Sallie in surface water. The present eutrophic condition of the lake cannot be attributed to groundwater flow. However, for other lakes, which have similar groundwater inflow but smaller surface inflow, groundwater may be expected to play a major role in the nutrient dynamics of the lake.

\section{SUMMARY}

The nutrient contribution of groundwater in glacial outwash terrain was evaluated at Lake Sallie in north-central U.S.A. ( $46^{\circ} 46^{\prime}$ N., $95^{\circ} 54^{\prime}$ W.). Groundwater entering the lake was collected with seepage meters consisting of bottomless cylinders vented to a thin membrane bag. A theoretical flow net and comparison of nutrient concentrations in well and seepage water indicated that seepage meters can be used in high velocity discharge areas to obtain site-specific water samples of groundwater for nutrient analyses. 
Based on an average value of $0.25 \mathrm{mg} / 1 \mathrm{PO}_{4}$, groundwater inflow along an $800 \mathrm{~km}$ segment of shoreline transported $37 \mathrm{~kg}$ of phosphorus per year into the lake. Groundwater inflow was nitrate rich along shoreline adjacent to land used for agriculture and lakeside septic tanks, but there was no apparent pattern regarding land use and phosphorus content of groundwater inflow. A nearby eutrophic lake was a suspected source of phosphorus in groundwater inflow.

Because surface flow has carried large quantities of nitrogen and phosphorus into this lake, its present eutrophic condition cannot be attributed to nutrient influx by groundwater. However, ground water nutrient influx could be highly significant in other lakes where surface nutrient influx is small.

\section{ACKNOWLEDGEMENTS}

This work was supported in part by a grant from the Pelican River Watershed awarded to Dr. Joe K. Neel and much of the data included in this paper was part of the author's Master's thesis at the University of North Dakota. Travel funds to the meeting of Groundwater Ecologists, Schlitz, Fed. Rep. of Germany were provided by a grant to Dr. John Cairns, Jr. from the E. I. du Pont de Nemours and Company educational aid program. Thanks to Lee Clayton, Quentin Gehle and Belva Lee for critical reading of the manuscript.

\section{ZUSAMMENFASSUNG}

Die Nährstoffzufuhr des Grundwassers eines Gletcherauswasch-Geländes wurde am Sallie See in Nord-Zentral U.S.A. $\left(46^{\circ} 46^{\prime} \mathrm{N}, 95^{\circ} 54^{\prime}\right.$ W) bestimmt. Das in den See fließende Grundwasser wurde mit Sickermeßgeräten gemessen, die aus einem bodenlosen Zylinder bestanden, an dem oben eine Polyäthylentüte angebracht war. Ein angenommenes Strömungsnetz und Vergleiche der Nährstoffkonzentrationen in Brunnen- und Sickerwasser haben gezeigt, daß Sickermeßgeräte in schnellströmenden Ausflußgebieten verwendet werden können, um für Nährstoffanalysen standortbezogene Grundwasserproben zu erhalten.

Bezogen auf einen Durchschnittswert von $0,25 \mathrm{mg} \mathrm{PO}_{4} / 1$ beträgt die Grundwasserfracht entlang des $800 \mathrm{~m}$ langen Seeufers $37 \mathrm{~kg}$ Phosphor im Jahr. Obwohl der Grundwasserzufluß nitratreich war - das Ufer grenzte an landwirtschaftlich genutzte Flächen und an Sickergruben - konnte keine eindeutige Beziehung zwischen der Landnutzung und dem Phosphorgehalt des Grundwasserzuflusses festgestellt werden. Als Grund dafür käme ein nahegelegener eutrophierter See in Frage.

Der gegenwärtige Nährstoffreichtum kann nicht auf den Nährstoffzustrom des Grundwassers zurückgeführt werden, da das Oberflächenwasser große Mengen von Stickstoff und Phosphor in den See transportiert. Dagegen gewinnt die Nährstoffzufuhr in den Seen durch das Grundwasser dort an Bedeutung, wo die Oberflächenzufuhr gering ist.

\section{REFERENCES}

AMERICAN PUBLIC HEALTH ASSOCIATION, 1965. Standard Methods for the Examination of Water and Wastewater. 12th ed. American Public Health Association, New York.

AMERICAN PUBLIC HEALTH ASSOCIATION, 1971. Standard Methods for the Examination of Water and Wastewater. 13th ed. American Public Health Association, New York.

CEDERGREN, H. R., 1968. Seepage Drainage and Flow Nets. John Wiley and Sons, Inc., New York.

DOMINICK, D. D., 1971. Methods for Chemical Analysis of Waters and Wastes. Environmental Protection Agency. U. S. Government Printing Office, Washington.

HASLER, A. D. and B. INGERSOLL, 1968. Dwindling lakes. Natural History, 77: 8-9.

LEE, D. R., 1975. A device for collecting seepage into lakes. Manuscript in preparation.

MCBRIDE, M. S., 1972. Hydrology of Lake Sallie, northwestern Minnesota, with special attention to ground water - surface water interaction. Master's Thesis, University of Minnesota, Minneapolis. 
MANN, W. B. and M. MCBRIDE, 1972. Hydrologic budget of Lake Sallie, Minnesota. 800-D Prof. Pap. U. S. geol. Surv.

PETERSON, S. A., W. L. SMITH, and K. W. MALUEG, 1974. Full-scale harvest of aquatic plants: nutrient removal from a eutrophic lake. J. Wat. Pollut. Control Fed., 46: 697-707.

POPOV, O. V., 1972. Practical tasks in the study of the interaction between surface and groundwaters. Sov. Hydrol.: Sel. Pap., 1: 1-9.

ROSE, C. W., 1972. Rural wastes: ideas needed. Wat. Wastes Engng, 9: 46-47.

SCHRAUFNAGEL, F. H., R. B. CORY, A. D. HASLER, G. F. LEE and R. L. WIRTH, 1967. Excessive water fertilization. Mimeograph. Report to the Water Subcommittee Natural Resources Committee of State Agencies, Madison, Wisconsin.

STEPHENSON, D. A., 1971. Groundwater flow system analysis in lake environments, with management and planning implications. Water Resources Bull. 7: 1038-1047.

UTTORMARK, P. D., J. D. CHAPIN, and K. M. GREEN, 1974. Estimating nutrient loadings of lakes from non-point sources. Environmental Protection Agency 660/3-74-020 U.S. Government Printing Office, Washington. 